Please do not remove this page

RMIT

UNIVERSITY

\title{
A typology for clients' multi-project environments
}

Blismas, Nick; Sher, William; Thorpe, Anthony; Baldwin, Andrew

https://researchrepository.rmit.edu.au/esploro/outputs/9921858679501341/filesAndLinks?institution=61RMIT_INST\&index=null

Blismas, N., Sher, W., Thorpe, A., \& Baldwin, A. (2004). A typology for clients' multi-project environments. Construction Management and Economics, 22, 357-371. https://doi.org/10.1080/01446190310001649047 Document Version: Accepted Manuscript

Published Version: https://doi.org/10.1080/01446190310001649047

Repository homepage: https://researchrepository.rmit.edu.au

(C) 2004 Taylor \& Francis Ltd

Downloaded On 2023/04/26 21:31:27 +1000

Please do not remove this page 


\title{
A Typology for Clients' Multi-Project Environments
}

\author{
NICK BLISMAS ${ }^{1 *}$, WILLIAM SHER ${ }^{2}$, ANTONY THORPE $^{3}$ and ANDREW \\ BALDWIN $^{4}$ \\ ${ }^{1}$ School of Property, Construction and Project Management, RMIT University, Melbourne, Victoria, \\ 3000, Australia \\ ${ }^{2}$ Department of Building, University of Newcastle, Callaghan, NSW 2308, Australia \\ ${ }^{3}$ Department of Civil and Building Engineering, Loughborough University, Loughborough, \\ Leicestershire, LE11 3TU, UK \\ ${ }^{4}$ Department of Building \& Real Estate, The Hong Kong Polytechnic University, Hung Hom, \\ Kowloon, Hong Kong \\ *Corresponding author
}

Construction management research and practice is dominated by a single project paradigm. This does not reflect the true nature of many construction clients who have large multi-project portfolios. Traditional single project management strategies are usually adopted for managing such portfolios with limited success. The literature suggests that programmes, within portfolios, require different forms of management in order to optimise project delivery. In order to better understand these portfolios and thereby allow the exploration of new forms of management, a typology has been developed mapping out the various features of client's construction portfolios. The resultant typology provides a simple method for identifying the programme composition of a portfolio, highlighting the expected features of each programme type, and thereby directing management attention to the main aspects of each programme that can be optimised for efficiency. Six cases of client's construction project portfolios were studied using a highly structured, replication logic, case study methodology. A typology of clients' multi-project environments was developed and validated through literal and theoretical replication between cases. Three main types emerged as descriptive of programmes within client's construction portfolios; Bounded programmes, Target programmes and Rolling programmes. The distinctive features of each type suggest that programme-specific approaches may be necessary for the successful delivery of projects within client's construction portfolios.

Keywords: Case studies, multi-projects, portfolio, programmes, typology

Abstract word count: 211

Paper word count (excluding abstract, references and tables): 4736 


\section{Introduction}

Most discussion of projects in general project management literature centres on either single projects or multiple projects managed simultaneously (Evaristo \&Van Fenema, 1999). Authors overwhelmingly concur that general project management literature is heavily biased towards the single project paradigm, with little written on the multi-project environment (for example Payne, 1995; Reiss, 1996; Eskerod, 1996; Tsai \& Chiu, 1996; Partington, 1996; Levy \& Globerson, 1997; Van der Merwe, 1998; Evaristo \& Van Fenema, 1999). However, many projects are part of a programme of work or a portfolio undertaken within a clearly identified business plan. Turner and Speiser (1992) contend that by far the greatest project activity takes place within portfolios, or programmes of medium to small sized projects, and not the traditional, large projects with dedicated teams of people. The single project paradigm which dominates the literature of both project and construction management research does not accurately reflect the reality of many construction clients, who have large ongoing construction portfolios rather than one-off construction projects.

A review of the top twenty five client organisations in the UK for 1998 and 1999 conservatively shows that multi-projects accounted for $10 \%$ of the entire industry's output or as much as 30\% of contractors' output (Blismas, 2001). Similar figures for 2000-2002 (Construction News, 2001-2003) show that the top clients' multi-project construction portfolios alone continue to procure between £7-9bn of construction work per annum. The implications for the remainder of the industry, including SMEs, are therefore enormous. Further secondary analysis of data from Kometa et al (1995) and Chinyio et al (1998a,b), demonstrate that the majority of clients surveyed 
initiated numerous construction projects annually, alluding to the suggestion that the industry operates with a significant contingent of multi-project clients.

Despite the significance of client's multi-project environments (MPE), there is a lack of construction related research on this topic. Research and academic publications on multi-project and programme management are generally restricted to disciplines outside construction with a resultant lack of comprehensive guides to managing multi-projects in construction. Most research on programmes, multi-projects and portfolios emanates from a range of disciplines such as communications, retail, manufacture, organisational management and software development (Abdullah \& Vickridge, 1999, 2000). Theoretical underpinning of the MPE within construction is required in order to provide the platform for developing managerial guides to managing portfolios of projects.

The general lack of research into multi-project environments, has been largely due to the false notion that project principles apply equally to a group as they do to individual projects. Multi-projects have tended to be treated as monolithic projects (Reedy, 1983), even though unique problems, particularly regarding their management have been identified by several authors (for example Reedy, 1983; Loftus, 1999; Abdullah \& Vickridge, 1999). The management of multi-projects and programmes is not simply an aggregate of single project efforts and as such requires unique approaches, techniques and tools - a view asserted and expounded by numerous authors such as Reedy (1983), Platje and Seidel (1993), Turner (1993), De Maio et al (1994), Palmer (1994), Meridith and Mantel (1995), Levy and Globerson (1997), Lonergan (1994), Sandvold (1998) and Williams (1999). Most authors for 
instance emphasize that scheduling and allocation of resources is more complex than that of single projects. There are enough differences between multi-projects and traditional projects to question the applicability of straight project management approaches (Olford, 1992). Attempts to aggregate single projects, often with minor commonalities, into one large project for management and co-ordination have been unsuccessful (Platje \& Seidel, 1993). Different techniques need to be developed to deal with the added complexity and issues that surround portfolios of projects within organisations.

In addition to the challenges posed by project multiplicity, inter-project difficulties further contest the view that project management is truly generic. One of the general reasons for project failure is that management techniques applied to a project may not always suit the project's requirements or characteristics. Different types of project, within different contexts, require differentiated project management approaches (Gareis, 1991, 2000; Evaristo \& Van Fenema, 1999). An organisation may have a variety of different kinds of programmes, each oriented to one of a variety of key resultant areas of that enterprise (Parti, 1995).

Categorisation of projects (and programmes) into types provides the basis for an organisation to develop specific planning and management tactics, as well as to determine the effort and resources that the undertaking would require (Ireland, 1997). Understanding project and programme types and the influences upon them constitutes a significant contribution to the understanding and management of these undertakings. Typologies serve to group programmes into types that exhibit similar traits, attributes or origins. Identifying programme types better serves the strategic 
objectives of an organisation and improves the attainment of short term goals for business operations, while also enabling the application of similar principles of design, management and process.

This paper addresses this particular short-fall in construction management literature by providing a detailed typology of programmes within construction client's multiproject environments. The broad aim of the research, of which this typology forms one part, was to gain a deeper understanding of the factors that influence project delivery within the multi-project environment (MPE) of construction clients. Further it sought to investigate the interaction between these factors, whilst also developing a typology of the MPEs of construction clients. Contending that the forces behind the MPE of construction clients are different to those traditionally viewed within the single project paradigm, an exploratory research approach was necessary. The research sought to uncover these factors without the undue influence of singleproject thinking, and consequently adopted a proposition-guided inductive research process.

\section{Definitions}

Due to different, and often interchangeable, uses of common project-related terms, it is necessary to define how 'multi-project environment', 'portfolio' and 'programme' are used in this paper.

Archer and Ghasemzadeh (1999) define a project portfolio as a group of projects that are carried out under the sponsorship and/or management of a particular organisation. This definition is extended slightly within this paper to describe a 
collective group of construction projects and programmes within an organisation, with no inference to the manner in which they are organised or managed. Multiproject environment is simply used to emphasise the multiplicity of projects in an organisation, which may not be as well conveyed using the term portfolio.

Programmes are groupings of projects within the broader portfolio defined above. Definitions of 'programme' within the multi-project context abound, yet a survey of 19 'programme' and 17 'programme management' definitions revealed a diffusion of defining characteristics (see Blismas (2001) for a detailed treatment of projectrelated definitions). In general a programme is a framework that; consists of multiple interdependent projects; is long-term or indefinite; focuses on the benefits or strategic aims of an organisation, provides common purpose between projects; and is usually a large undertaking. Essentially, all programmes involve a number of projects run within groups, and exhibit some form of interaction between projects. Pellegrinelli’s (1997) definition draws these points together succinctly;

'A programme is a framework for grouping existing projects or defining new projects, and for focusing all the activities required to achieve a set of major benefits. These projects are managed in a co-ordinated way, either to achieve a common goal, or to extract benefits which would otherwise not be realised if they were managed independently.'

\section{Methodology}

A general literature review was undertaken to establish previous research, identify definitions, terminology and general construction trends. This literature review together with exploratory interviews with managers of consultant and client organisations helped define the various types of projects and programmes and develop a conceptual framework of current knowledge within which to relate the 
different programme types. The scarcity of resources on the subject within construction-related disciplines dictated that literature from other disciplines formed the major proportion of the review. Without an a piori knowledge of the nature of the construction MPE, it was not possible to deductively propose hypotheses to guide the exploration of the research problem. Thus, it was necessary to devise propositions to define the boundaries of the study, whilst also making prejudices of the researcher explicit at the outset of the research. Existing non-construction project typologies and exploratory interviews were examined and abstracted to form the starting propositional basis for a construction typology.

A multiple case study design, using replication as the underlying logic (Yin, 1994; Eisenhardt, 1989), was adopted. The unit-of-analysis was identified as clients' construction portfolios, with individual programmes forming embedded units. A highly-structured research design was favoured to satisfy concerns of validity and robustness of the case study approach, whilst still allowing flexibility to explore features not identified in the literature or exploratory interviews. Six cases were selected for the predicted literal and theoretical replications of their results. A summary of these cases is shown in Table 1. Each case was analysed independently and compared in cross-case analyses.

Personal semi-structured interviews, programme documentation and published documentation formed the primary data sources within each case. Triangulation of data was achieved through multiple intra-case interviews, embedded unit studies, and multiple data sources. The interview data alone, once transcribed amounted to just under 200,000 words. Together with the electronically captured documentation, over 
100 data files, representing individual interviews and documents, were produced. These data were managed and analysed using the Nvivo ${ }^{\mathrm{TM}}$ computer-aided qualitative data analysis software. Analysis of the qualitative data included codification, thematic grouping and causal mapping.

Matrices were used to reduce the data into a manageable format from which organisational structures, typologies and casual networks were constructed. The matrices were constructed from nodes produced by the Nvivo ${ }^{\mathrm{TM}}$ software. Each passage coded into the node was carefully examined and the main themes noted. The findings were expressed as networks and matrices. Characteristic features of the propositions were organised into matrices and groups so that cross-case analysis was possible.

\section{Typology Development}

A review of existing literature was initiated to establish how different projects, project types and programme types were identified by previous researchers. Researchers have grouped projects into types that exhibit similar traits, attributes or origins. Different researchers have classified projects using categories such as; the origin of projects (Hackney and Humphreys, 1992), industries (Turner, 1993; Lock, 1996), features (Archibald, 1992; Turner, 1993; Lock, 1996; Reiss, 1996) and orientation of deliverables (Reiss 1996; James, 1996; McElroy, 1996; Levene \& Braganza, 1996). Others, such as Project Management Institute’s (2000) 'Body of Knowledge' attempt no classification of projects or programmes, advocating the view that project and project management principles are generic. The different 
project classifications proposed by different authors may be considered in terms of organisation-related categories (Table 2) or project-related categories (Table 3).

Archibald (1992), Hackney and Humphreys (1992), Lock (1996), Gareis (1998), and Turner (1993) categorise projects based on general organisational categories e.g. research projects, management projects, civil engineering, construction and mining projects etc. (See Table 2). Examination of this table shows that in general, projects fall between harder, engineering type projects and softer, management type projects. The extent to which these types appear within an organisation greatly depends on the industry to which the organisation belongs. E-commerce organisations for example may have little or no capital projects, whereas utility organisations will have large construction portfolios. Construction projects fall firmly within the categories on the left hand side of Table 2, which specifically describes capital, engineering and construction projects. Construction projects are unlikely to be the only projects that these clients manage; they will also usually undertake management, $R \& D$, marketing projects and programmes concurrently with their construction project portfolio.

Table 3 shows a classification based on project-related categories. This table emphasises the general dichotomy between hard, physical, development projects and softer, intangible, change type projects. Construction projects tend strongly towards the former, although some of the concepts, particularly of programmes and multiprojects, arise from the softer band. The softer management oriented projects, which dominate programme management research, do not contend with the same issues as construction or capital projects, emphasising human resources and neglecting the 
unique aspects of construction projects. Many of the different categories do however overlap, describing identical features.

Although the categories proposed by these authors are numerous, none describe the relationships that exist between different projects undertaken by a single client, or body. What then are the criteria that should be used to group projects in a MPE?

Table 4 presents classifications particular to the multi-project environment. Project types and categories in multi-projects and programmes vary between loose associations and rigid models describing detailed configurations and features. The number of criteria for describing MPE is low when compared to the criteria for traditional projects. Relationships between projects are almost exclusively referred to in terms of resource sharing and competition, without broader overarching descriptions of types. The repetitive aspects of multi-projects have been rightly identified as an important criterion for grouping projects to best apply appropriate management principles. Reiss (1996) categorised projects as ranging between 'strangers', which are usually high risk, stochastic and for which there is little experience in the organisation, through to 'runners', which are continuous and present lower risks. Gareis (1998) uses a simpler dichotomy to distinguish between these two extremes; 'unique' versus 'repetitive'.

Programme types and models vary greatly. The wide variety and interchangability of terms inhibits the unambiguous identification of distinct types. Depictions of programmes have often been simple and vague, showing them as either a series of individual projects, or as phases within a larger product development programme 
(see Morris \& Hough, 1987 for instance). Ferns (1991), Reiss (1996) and Pellegrinelli (1997), do however, offer detailed configurations that model a range of types within the MPE of organisations. Pellegrinelli (1997) and Ferns (1991) offer three types each, and Reiss (1996) four. These models are noticeably inappropriate for direct application to construction MPEs, the focus being on softer issues such as business change, R\&D, new product development (NPD) and management-centred MPEs.

Although obvious variances between these researchers views exist, common themes emerge from their typologies, which formed the basis of propositional types for a construction-specific programme typology. The terms 'Objective Programmes', ‘Strategic Programmes’ and ‘On-going Programmes’ were initially adopted for ease of reference between these authors different types. The 'Objective' types tend to describe programmes comprising projects that make-up a single objective, and can therefore be well-defined and focused with a definitive outcome marking the end of the programme. 'On-going' types tend to be ongoing programmes emanating on a continuous basis within organisations, impacting upon the organisation's business. Resource sharing and co-ordination are key factors in this type. 'Strategic' programmes are those frameworks through which ever-changing strategic goals and initiatives are planned and completed. The goals of these projects change as the strategies of the organisation are amended to meet new challenges from the external environment.

Using these three basic programme themes, and their main defining characteristics, a detailed typology of construction client's MPE was advanced. These initial types 
were largely expanded and altered to reflect the unique features of the construction environment. The three propositional types were renamed to further indicate the uniqueness of these programme types. The features and verification of the typology is described in the following section.

\section{Multi-Project Typology for Construction}

The typological themes, based on the models of Ferns (1991), Reiss (1996) and Pellegrinelli (1997) provided a basis for developing a construction-specific programme typology. These suggested that programmes vary according to their origins, objectives, project composition and execution. Although the models on which this typology was developed were detailed, they clearly lacked applicability to construction portfolios. The basis of these models: the degree of programme definition and certainty was however used as the definitive criterion for developing the construction-specific programme typology.

Three models were advanced and following cross-case comparison shown to be supported by all cases. The models, named Bounded, Target and Rolling programmes, are points on a continuum rather than distinctive solitary models. Essentially they describe the degree of certainty associated with a programme. In addition, it should be noted that an organisation's construction project portfolio would usually comprise of a number of concurrent programmes, often of various types.

Four characteristics, relating to programme definition and certainty, were used as the main identifying features of each type. Time horizon, programme definition, 
programme objectives, and project sites were used to define a programme type. A further ten features were advanced as potential characteristics of the three models, all of which would be exhibited to some degree, in each type. A summary of the three programme types is provided in Table 5. Each type is briefly explained below.

\section{Bounded programmes types}

Bounded programmes, as the name suggests, are those that are well-defined, and of limited scope. They have definite conclusions, and would be self-contained packages of work with minor or no subsequent programme. The client objectives would be clear, and substantially independent of economic fluctuations. They would be a stepchange for the organisation. Table 6 describes the specific features of Bounded programmes.

High certainty is the definitive feature of this programme type. The marks of this character, are the potential for continuity, low client flexibility, bulk procurement and substantial supply-chain benefits. The stability offered is ideal for planning project sequences, ordering products within acceptable lead times, and fixing project details at very early stages. Efficiency benefits are potentially high, due to fixity, however these programmes are probably not as common as the other types.

Case A provides a clear example of this type of programme. An international oil company undertook a global re-imaging programme that sought to refurbish all existing outlets to the same visual specifications. The programme was divided and managed at national levels. The programme for the South African region, forming case A, displays the typical characteristic of this group by its high level of definition. 
A budget of ZAR 207million (at 1997 prices), time horizon of 3 years and clear scope of works were rigidly set and applied to a known network of 850 properties across South Africa. With these parameters well-defined, it was possible to undertake the programme, without the uncertainty inherent in other programme types. The programme ended when all outlets were converted, all further works being undertaken as maintenance under a separate contract and programme.

\section{Rolling programme types}

Rolling programmes represent the opposite type of programme to Bounded programmes. Their loose on-going nature is a result of the client organisation's wish to develop their network in close accordance to environmental indicators, without over-committing to fixed capital. Table 7 details the features of Rolling programmes.

Although, organisational objectives and project definitions may be well-defined, the rate, mixture and number of projects comprising the programme will be highly variable and generally unknown. The client does not target any programme output, but relies on environmental conditions to shape the programme for the next period. The resultant project stream can be highly variable and unpredictable, yet continuous over the long-term.

The stochastic, yet long-term continuous nature, of the programme makes it rather peculiar in the benefits that can be derived from the procurement and management approaches adopted. The uncertainty associated with the programme results in a cautious approach by the client towards predicting workloads. Clients will usually form long-term relationships with suppliers, but will not commit to any specified 
workload numbers or volumes, as these are variable. Suppliers need to adapt their operations to supply services or products as the developing programme dictates. Clients with Rolling programmes would try and approximate Target programmes to encourage stability and garner the associated benefits.

The 'raze and rebuild' programme within case C illustrates the main characteristics of a rolling programme. This programme, within a global energy company's retail property portfolio, was one of many programmes that comprised the construction work of the division. The programme involved the demolition and rebuilding of older retail outlets on an ongoing basis. Unlike a bounded programme, funds were not specifically allocated to this programme, being incorporated within the annual budgetary cycle. Project numbers would be loosely determined at the beginning of each cycle, although subject to regular changes. Due to its vagueness, the economic environment exerted a strong influence over the constitution of the programme. Issues such as oil prices, dealer contracts, and changing client objectives would cause projects to be added or removed from the programme in an unsystematic manner that proved disruptive to project delivery.

\section{Target programme types}

The Target programme is a hybrid form of the previous two types, exhibiting the open flexible nature of Rolling programmes, yet with an element of definition and direction displayed by Bounded programmes. Table 8 details the features of Target programmes. 
Target programmes arise from an organisation's strategies that clearly forecast a long-term need for change to their facilities network. This would be translated into a definitive figure, which becomes the driving force for the programme. However, as these programmes usually involve the need for land acquisition, their ideal target rates may be highly unstable. These programmes can rarely be made into Bounded programmes due to uncertainty with a critical resource such as suitable land for development. In addition, economic changes may dictate that these programmes must change their production rates, or even target numbers, to continue operating at optimum profitability.

The variability displayed by Target programmes is slightly stabilised by the definitive goals, thus allowing more continuity advantages to be pursued than would be the case with Rolling programmes. These are probably the most common programme types of the three defined.

Case D provides a close correlation to the characteristics of a target programme. The programme was part of a global hotel and leisure group's attempt to expand their network of hotels into Britain, and thereby establish themselves as a leading brand. Their programme was driven by a medium-term target of 125 hotels in the UK within 5 years. As their land base was non-existent, the targets were dependent on the feed of land or existing properties into the programme. Targets, budgets and estimates were therefore constantly revised to try and achieve the broad target. The clear target arose from the organisation's objectives, yet like the rolling programme was subject to revision as circumstances changed. 


\section{Cross-case validation}

The typology models above were tested against the programmes that comprised the six research cases. Table 9 lists the features in the first column, and eight distinct programmes identified within the six cases. The first four features identified the programme type, whilst the remaining features were tested for conformity to the typology.

The typological models replicated well between the case programmes. Case programmes A, C1 and E2 displayed close fits with the Bounded programme type. E2 lacked some information within the cases and therefore the results should be treated with caution. C1 displayed very high levels of innovation and creativity brought about by the progressive attitude of the alliance and Joint Venture partnership, highlighting the possibility of great efficiency gains if organisations are focussed at the commencement of a Bounded programme.

Cases C2 and E1, which were identified from the four main features as Rolling in character, likewise displayed a good overall fit with the Rolling programme type. The exception to the Project Interaction feature, displayed by case E1, could be attributed to the unusual nature of its facilities in which they are structurally and functionally linked. This feature would not normally be expected in a client's construction portfolio, which usually consists of multiple disparate and independent facilities.

Three programmes were identified from the cases as displaying Target programme features. Replication between these was good, although some features did not match 
with the typology model as expected. However, these programmes are by nature hybrid forms of the other two types and they would therefore be expected to display certain features more akin to one of those types.

The cases again emphasise that organisations are engaged in several simultaneous programmes within their construction or property portfolios. All cases provided evidence of this within the data. Within these portfolios it is evident that further programme types may exist. These are briefly discussed in the following section.

\section{Other models}

Although the typology described above is generally inclusive of most programme types, further types are evident within the case data. All cases, except F, displayed specific maintenance programmes for their facilities, which were distinct from all other programmes. These are more akin to Rolling programmes, as their workloads may be stochastic, although routine maintenance programmes introduce Bounded, or even Target characteristics. In addition, these are generally procured through termcontracts and run independently either as facilities management or in conjunction with property departments.

It is proposed that these form a fourth programme type, due to the unique issues yet repeatable features they display. Insufficient data existed within the cases to develop a typological profile for this programme type.

A fifth programme type is also likely within the entire construction portfolio of a client's organisation, although was only obliquely implied in case B. These would be 
instances where construction clients may undertake large and unusual projects that would not fall into any of their regular programmes. Project's whose size or scope is sufficiently out of character to require specific attention, more akin to a monolithic project. Case B, for instance, constructed a new office block and warehouse for their operations which was a one-off project unlike their regular network projects. Its bespoke nature and size precluded it from being included within the rolling or target programme, and therefore was treated independently.

Evidence is therefore persuasive that a further two programme types should be added to the typology developed above, namely, Maintenance programmes and Monolithic projects, although both these groups would require further investigation to verify.

\section{Implications}

The implications of the typology developed above can be viewed at both an industrial and organisational level. Industrially, the typology has implications for the industry's single-project view of construction. With globalisation and favourable economic trends in the UK, organisations are increasingly seeking to extend their brands and services into larger markets. Proximity to their markets requires organisations to acquire large facility networks across vast areas. Organisations will therefore increasingly face situations in which they build, maintain and refurbish a large portfolio of properties to sustain their core activities. Yet management of these portfolios still rely on persons trained within the single-project paradigm, as discussed in the introduction. 
This single project paradigm focuses individuals on an isolated contract, without an appreciation of the multi-project nature of the industry. The industry has however started to shift emphasis towards building supply-chain relationships with repeat clients (i.e. those with multi-project environments). An appreciation of these typologies should further solidify this change in outlook, encouraging long term relationships based on clients’ programmes.

Organisationally, the typology identifies the major differences between programmes within a portfolio, responding to suggestions that diverse management approaches are necessary for the various types. Programmes with high levels of certainty, such as Bounded and some Target, could be procured more efficiently as entire programmes rather than individual projects, whereas rolling programmes would rely on groups of preferred suppliers negotiating projects with the client as they occurred. The unique characteristics of the different programmes further support the literature discussed earlier, which asserts that a rigid and homogenous management framework for all projects and programmes in a portfolio is neither efficient nor effective. Rather a programme-by-programme system that focuses on the particulars of each type is provided by the typology.

The typology developed within this paper is part of a larger research project, which also identified the main factors influencing programme delivery within portfolios. From the resultant influences, an Influences Model was derived showing the dynamics between these in the clients' project portfolio. Together with the typology, these three elements compliment each other to provide a framework for planning and managing construction portfolios and their constituent programmes in organisations. 
Unlike other programme management 'tools and techniques approaches', this research offers a unique theoretical framework that can be developed and adapted to specific situations.

\section{Conclusions}

The development of a construction-specific typology gave rise to three main types of multi-project programme within a client organisation's MPE. These were named Bounded, Rolling and Target programmes and developed into descriptive models that were successfully applied to the cases of the research. The three types of programme are based on the degree of project certainty within a programme. Certainty of programme composition, production rates and workloads, has significant consequences on process efficiency, and thus recognition of programme type may influence an organisation's management approach. The typology provides a simple method for identifying the programme composition of a portfolio, highlighting the expected features of each programme type. The profile generated directs management attention to the main aspects of each programme that can be optimised for efficiency. 


\section{References}

Abdullah, A.M. \& Vickridge, I.G. (1999) Best practice for MPM in the construction industry. Proceedings of RICS COBRA 1999 Conference - The Challenge of Change: Construction and Building for the New Millennium, Vol 2, 169-179, University of Salford, Salford.

Abdullah, A.M. \& Vickridge, I.G. (2000) The extent of multi-project management implementation in the UK construction industry. Proceedings of the 16th Annual Conference ARCOM, Vol 2, 137-146, Glasgow Caledonian University.

Archer, N.P. and Ghasemzadeh, F. (1999) An integrated framework for project portfolio selection. International Journal of Project Management, 17(4), pp207-216.

Archibald, R.D., (1992) Managing high-technology programs and projects 2nd ed. New York: John Wiley \& Sons Inc.

Blismas, N.G. (2001) Multi-project environments of construction clients. Unpublished PhD Thesis, Loughborough University, Loughborough, United Kingdom.

Bryman, A. (1989) Research Methods and Organisation Studies. Contemporary Social Research, 20 (Ed: Bulmer, M.), London: Routledge. 
Chinyio, E.A., Olomolaiye, P.O. and Corbett, P. (1998a). An evaluation of the project needs of UK building clients. International Journal of Project Management, 16(6), 385-391.

Chinyio, E.A., Olomolaiye, P.O., Kometa, S.T. and Harris, F.C. (1998b). A needsbased methodology for classifying construction clients and selecting contractors. Construction Management and Economics, 16, 91-98.

Construction News (2001-2003). Contracts League Tables, 18 January 2001; 24 January 2002; 23 January 2003. ISSN 0010-6860.

De Maio, A., Verganti, R. and Corso, M. (1994) A multi-project management framework for new product development. European Journal of Operational Research, 78, 178-191.

Eisenhardt, K.M. (1989) Building theories from case study research. Academy of Management Review, 14(4), 532-550.

Eskerod, P. (1996) Meaning and Action in a multi-project environment. International Journal of Project Management, 14(2), 61-65.

Evaristo, R. and van Fenema, P.C. (1999) A typology of project management: emergence and evolution of new forms. International Journal of Project Management, 17(5), 275-281. 
Ferns, D.C. (1991) Developments in programme management. International Journal of Project Management, 9(3), 148-156.

Gareis, R. (1991) Management by projects: the management strategy of the 'new' project-oriented company. International Journal of Project Management, 9(2), 71-76.

Gareis, R. (1998) The new project management paradigm. Proceedings Vol. 1, 14th World Congress on Project Management, Slovenia, June 10-13, 290-296.

Gareis, R. (2000) Programme management and project portfolio management: New competencies of project-oriented companies. Proceedings of the IRNOP IV Conference, "Paradoxes of Project Collaboration in the Global Economy: Interdependence, Complexity and Ambiguity”, Sydney, Australia.

Gray, R.J. (1997) Alternative approaches to programme management. International Journal of Project Management, 15(1), pp5-9.

Griffith, A. \& Headley, J.D. (1995) Developing an effective approach to the procurement and management of small building works within large client organisations. Construction Management and Economics, 13, pp 279-289.

Hackney, J.W. and Humphreys, K.K. (Ed) (1992) Control and management of capital projects, 2nd ed. London: McGraw-Hill Inc. 
Ireland, L.R. (1997) Managing multiple projects in the twenty-first century. Paper presented to Project Management Institute 28th Annual Seminars \& Symposium, Chicago, Illinois, 29 Sept - 1 Oct, 471-477.

James, G. (1996) Managing business change through programmes. Proceedings of seminar A, Exploring Programme Management, Project Management Exhibition 1996.

Kometa, S.T., Olomolaiye, P.O. \& Harris, F.C. (1995) An evaluation of clients' needs and responsibilities in the construction process. Engineering, Construction and Architectural Management, 2(1), 57-76.

Levene, R.J. and Braganza, A. (1996) Controlling the work scope in organisational transformation: a programme management approach. International Journal of Project Management, 14(6), 331-339.

Levy, N. and Globerson, S. (1997) Improving multiproject management by using a queuing theory approach. Project Management Journal, 28(4), 40-46.

Lock, D. (1996) Project Management, $6^{\text {th }}$ Ed. Vermont: Gower Technical Press Ltd.

Loftus, J. (1999) The clients problem. In: Loftus, J.(Ed) Project management of multiple projects and contracts. London: Thomas Telford.

Lonergan, K. (1994) Programme Management. Project, APM, July 1994. 
McElroy, W. (1996) Implementing strategic change through projects, International Journal of Project Management, 14(6), 325-329.

Meredith, J.R. and Mantel, S.J., (1995) Project Management: A managerial approach. New York: John Wiley \& Sons Inc.

Morris, P.W.G. and Hough, G.H. (1987) The Anatomy of Major Projects. Chichester: John Wiley \& Sons.

Olford, B. (1992) Multi-project management - An oxymoron? Proceedings of Seminars on Project Management, Project Management North 1992 (Project Manager Today).

Palmer, B. (1994) Programme Management basic concepts. Proceedings of Seminars session E - Programme Management, Project Management Exhibition 1994.

Parti, E.W. (1996) Issues in pursuing quality in facility program development. Journal of Architectural Engineering, 2(1), 32-40.

Partington, D. (1996) The project management of organisational change. International Journal of Project Management, 14(1), 13-21.

Payne, J.H. (1995) Management of multiple simultaneous projects: a state-of-the-art review. International Journal of Project Management, 13(3), 163-168. 
Pellegrinelli, S. (1997) Programme management: organising project-based change. International Journal of Project Management, 15(3), 141-149.

Platje, A. and Seidel, H. (1993) Breakthrough in multiproject management: how to escape the vicious circle of planning and control. International Journal of Project Management, 11(4), 209-213.

Project Management Institute (PMI) (2000) A Guide to the Project Management Body of Knowledge (PMBOK). Sylva USA: PMI Communications.

Reedy, J.H., (1983) Unique issues of multi-project management. In D.I. Cleland and W.R. King, eds. Project Management Handbook, London: Van Nostrand, 1983.

Reiss, G. (1996) Programme management demystified, managing multiple projects successfully. E \& FN Spon: London.

Sandvold, Ø. (1998) Programme management: Added value of increased overhead? Proceedings Vol. 1, $14^{\text {th }}$ World Congress on Project Management, Slovenia, June 1013, 161-165.

Simister, S. (1994) An investigation into the influences on construction professionals’ working practices. Unpublished $\mathrm{PhD}$ thesis, University of Reading. 
Tsai, D.M. and Chiu, H.N. (1996) Two heuristics for scheduling multiple projects with resource constraints. Construction Management and Economics, 14, 325-340.

Turner, J.R. (1993) The handbook of project-based management: Improving the process of achieving strategic objectives. London: McGraw-Hill Book Company.

Turner, J.R. and Speiser, A. (1992) Programme management and its information systems requirements. International Journal of Project Management, 10(4), 196-206.

Van der Merwe, A.P. (1998) The history of project management: A search for world best practices. Proceedings Vol. $1,14^{\text {th }}$ World Congress on Project Management, Slovenia, June 10-13, 260-270.

Williams, T.M., (1999) The need for new paradigms for complex projects. International Journal of Project Management, 17(5), 269-273.

Yin, R.K. (1994) Case Study Research: Design and Methods 2nd Ed. London: Sage Publications Ltd. 
Table 1: Matrix comparing basic attributes, projects and programmes between the six cases.

\begin{tabular}{|c|c|c|c|c|c|c|}
\hline Factors & Case A & $\begin{array}{c}\text { Case B } \\
\end{array}$ & $\begin{array}{c}\text { Case C } \\
\end{array}$ & Case D & Case E & Case F \\
\hline $\begin{array}{l}\text { Geographic span of } \\
\text { operations }\end{array}$ & $\begin{array}{l}\text { Global, but case in } \\
\text { South Africa } \\
\end{array}$ & - England \& Wales & $\begin{array}{l}\text { - Global, but case in UK } \\
\text { and Benelux only }\end{array}$ & $\begin{array}{l}\text { - Global, but case in UK } \\
\text { only }\end{array}$ & - Great Britain & - English Midlands \\
\hline Network size & - Approximately 850 sites & $\begin{array}{l}105 \text { retail outlets (at end } \\
\text { of 1998) }\end{array}$ & $\begin{array}{l}\text { - } 1500 \text { sites in UK after } \\
\text { acquisition }\end{array}$ & - 80 hotels in UK & - Entire British mainland & $\begin{array}{l}\text { - Not applicable as built } \\
\text { to sell }\end{array}$ \\
\hline Facility type, size and grades & $\begin{array}{l}\text { Petrol stations of } \\
\text { different size, some with } \\
\text { shops, } \\
\text { - Graded to sales }\end{array}$ & $\begin{array}{l}\text { - Retail outlets (High } \\
\text { street and shopping } \\
\text { centres) } \\
\text { - Variously graded }\end{array}$ & $\begin{array}{l}\text { - Petrol stations of } \\
\text { different size, some with } \\
\text { shops, } \\
\text { - Graded to sales, }\end{array}$ & $\begin{array}{l}\text { - Hotels, } \\
\text { - Four grades, } \\
\text { - 87-141 room sizes }\end{array}$ & $\begin{array}{l}\text { Gas pipe utility } \\
\text { infrastructure, } \\
\text { compressors \& storage } \\
\text { facilities }\end{array}$ & $\begin{array}{l}\text { Domestic housing, } \\
\text { commercial \& } \\
\text { residential buildings }\end{array}$ \\
\hline Project types & $\begin{array}{l}\text { - New \& rebuild sites, } \\
\text { - Re-image programme of } \\
\text { whole network, } \\
\text { - Maintenance and } \\
\text { refurbishments } \\
\end{array}$ & $\begin{array}{l}\text { - } \text { Acquisitions in } \\
\text { expansion, } \\
\text { - Refurbishments, } \\
\text { - Re-branding, } \\
\text { - De-commissioning } \\
\end{array}$ & $\begin{array}{l}\text { - JV new sites, } \\
\text { - New builds, raise \& } \\
\text { rebuild, } \\
\text { - } \text { Minor capital works }\end{array}$ & $\begin{array}{l}\text { - New hotel construction, } \\
\text { - Refurbishment \& } \\
\text { maintenance, } \\
\text { - Conversions, }\end{array}$ & $\begin{array}{l}\text { Pipe extension, } \\
\text { modification, } \\
\text { compressors, } \\
\text { connections, } \\
\text { demolitions } \\
\end{array}$ & $\begin{array}{l}\text { Speculative housing, } \\
\text { commercial and } \\
\text { industrial speculation }\end{array}$ \\
\hline $\begin{array}{l}\text { Project numbers and } \\
\text { frequency within programmes }\end{array}$ & $\begin{array}{l}\text { - Re-image } 850 \text { sites over } \\
\text { 3 years, } \\
\text { - Peak } 300 \text { sites/year }\end{array}$ & $\begin{array}{l}\text { - Target of } 350 \text { stores by } \\
\text { 2001, at ave } 40 / \text { year, } \\
\text { - Currently below target }\end{array}$ & $\begin{array}{l}\text { - Variable between years, } \\
\text { - JV - } 100 \text { sites/3 yrs, } \\
\text { - Ave } 60 \text { rebuild/yr, } \\
\text { - Minor capital works - } \\
\text { ave } 150 / y r\end{array}$ & $\begin{array}{l}\text { - Target of } 125 \text { new } \\
\text { hotels in } 5 \text { years in UK, } \\
\text { - } 20 \text { major refurbishments } \\
\text { per year, } \\
\text { - Before programme ave } \\
\text { was } 1 \text { every } 16-18 \\
\text { months }\end{array}$ & $\begin{array}{l}\text { - } \text { Ave } 80 \text { projects/yr but } \\
\text { highly variable, } \\
\text { - Ave } 12 \text { major } \\
\text { pipelines/yr over 2-3 yrs } \\
\text { - } 2-3 \text { major compressor } \\
\text { works/yr } \\
\text { - } 400-500 \text { demolitions } \\
\text { over } 5 \text { yrs } \\
\end{array}$ & $\begin{array}{l}\text { 260-300 houses/year, } \\
\text { average }\end{array}$ \\
\hline $\begin{array}{l}\text { Project/programme costs and } \\
\text { budgets }\end{array}$ & $\begin{array}{l}\text { Budget ZAR207million, } \\
\text { Projects up to 350K, ave } \\
\text { 200K }\end{array}$ & $\begin{array}{l}\text { - Ave annual budget } \\
£ 2.5 \text { million, } \\
\text { - Project range £63-160K } \\
\text { (ave £80K) }\end{array}$ & $\begin{array}{l}\text { - Capex £52million/yr, } \\
\text { - Project range £300K- } \\
\text { £1million (ave between } \\
£ 500-700 K) \\
\end{array}$ & $\begin{array}{l}\text { - Economy £3m - upper } \\
£ 70 \mathrm{~m}\end{array}$ & $\begin{array}{l}\text { - } £ 20 \mathrm{~K}-£ 100 \mathrm{~m} \text {, } \\
\text { - Ave } £ 20 \mathrm{~m} / \text { project, } \\
\text { - Connection £250K }\end{array}$ & $\begin{array}{l}\text { - Ave £50million/yr } \\
\text { turnover }\end{array}$ \\
\hline $\begin{array}{l}\text { Programme and project } \\
\text { definition }\end{array}$ & $\begin{array}{l}\text { - Very well defined finite } \\
\text { programme, }\end{array}$ & $\begin{array}{l}\text { Overall } 5 \text { year target, } \\
\text { with adjustments to rate } \\
\text { of delivery, }\end{array}$ & $\begin{array}{l}\text { - JV well defined, } \\
\text { - Other programmes } \\
\text { variable and subject to } \\
\text { changes, targets given } \\
\text { every } 6 \text { months } \\
\end{array}$ & $\begin{array}{l}\text { - Target relatively firm, } \\
\text { but adjusted yearly as } \\
\text { circumstances dictate, }\end{array}$ & $\begin{array}{l}\text { - Very stochastic } \\
\text { programme, } \\
\text { - Demolition programme } \\
\text { very well defined }\end{array}$ & $\begin{array}{l}\text { Housing developments } \\
\text { well-defined though } \\
\text { phased for flexibility }\end{array}$ \\
\hline Programme time horizon & $\begin{array}{l}\text { - Accounts vary between } \\
3 \text { and } 4 \text { years, } \\
\text { - Ave project duration } 12 \\
\text { weeks lead, } 3 \text { wks } \\
\text { building, } 2 \mathrm{w} \text { signage }\end{array}$ & $\begin{array}{l}\text { - } 5 \text { year programme goal, } \\
\text { - Project ave } 12 \text { weeks } \\
\text { plan + 3-4 weeks works } \\
\text { + 9-11dys stock }\end{array}$ & $\begin{array}{l}\text { - Annual budget cycle, } \\
\text { - JV has own budget, } \\
\text { - Service and maint } \\
\text { contracts } \\
\text { - Ave project } 16 \text { weeks }\end{array}$ & $\begin{array}{l}\text { - Programme } 5 \text { years, } \\
\text { - Project durations } 52 \\
\text { weeks, }\end{array}$ & $\begin{array}{l}\text { - } \text { Annual budget } \\
\text { programme subject to } \\
\text { demand, } \\
\text { - Pipeline ave } 2.5 \text { yrs }\end{array}$ & $\begin{array}{l}\text { - Programmes based on } \\
\text { yearly target turnover of } \\
£ 50 \mathrm{~m}\end{array}$ \\
\hline
\end{tabular}


Table 2: Comparative table of Organisation-related typologies and classifications.

\begin{tabular}{|c|c|c|c|c|c|}
\hline Differentiation & \multicolumn{4}{|c|}{ Organisation-related Categories } & References \\
\hline \multirow{5}{*}{ General nature } & $\begin{array}{c}\text { Capital facilities } \\
\text { design and } \\
\text { construct }\end{array}$ & $\begin{array}{c}\text { Research, } \\
\text { production } \\
\text { development and } \\
\text { engineering }\end{array}$ & $\begin{array}{c}\text { Commercial } \\
\text { projects under } \\
\text { contract for } \\
\text { production or } \\
\text { services } \\
\end{array}$ & $\begin{array}{c}\text { Management } \\
\text { projects }\end{array}$ & Archibald (1992) \\
\hline & $\begin{array}{l}\text { Engineering - } \\
\text { market } \\
\text { requirements }\end{array}$ & $\begin{array}{l}\text { R \& D groups - } \\
\text { new products and } \\
\text { processes and } \\
\text { their introduction }\end{array}$ & $\begin{array}{c}\text { Corporate } \\
\text { engineering depts } \\
\text { - improvements to } \\
\text { prod. Process \& } \\
\text { equipment }\end{array}$ & $\begin{array}{l}\text { Operating staff - } \\
\text { improvement-type } \\
\text { projects }\end{array}$ & $\begin{array}{l}\text { Hackney and } \\
\text { Humphreys } \\
\text { (1992) }\end{array}$ \\
\hline & $\begin{array}{l}\text { Civil/construction/ } \\
\text { mining etc. }\end{array}$ & Research Projects & Manufacturing & $\begin{array}{c}\text { Management } \\
\text { Projects }\end{array}$ & Lock (1996) \\
\hline & $\begin{array}{l}\text { Development } \\
\text { projects }\end{array}$ & $\begin{array}{l}\text { Marketing } \\
\text { projects }\end{array}$ & $\begin{array}{c}\text { Contracting } \\
\text { projects }\end{array}$ & $\begin{array}{l}\text { Organisation } \\
\text { projects }\end{array}$ & Gareis (1998) \\
\hline & Engineering & Informatio & technology $\quad$ Or & anisational change & Turner (1993) \\
\hline
\end{tabular}

Table 3: Comparative table of Project-related typologies and classifications.

\begin{tabular}{|c|c|c|}
\hline Differentiation & Project-related Categories & References \\
\hline \multirow{3}{*}{$\begin{array}{l}\text { Facilities or } \\
\text { deliverables }\end{array}$} & Indirect facilities (for example retail) & $\begin{array}{l}\text { Griffith \& } \\
\text { Headley (1995) }\end{array}$ \\
\hline & $\begin{array}{l}\text { Soft intangible deliverables, like } \\
\text { business change }\end{array}$ & $\begin{array}{l}\text { Reiss (1996); } \\
\text { McElroy (1996); } \\
\text { James (1996) } \\
\end{array}$ \\
\hline & $\begin{array}{ccc}\begin{array}{c}\text { Realisation of primary } \\
\text { process }\end{array} & \begin{array}{c}\text { Realisation of secondary } \\
\text { process }\end{array} & \begin{array}{c}\text { Realisation of tertiary } \\
\text { process }\end{array} \\
\end{array}$ & Gareis (1998) \\
\hline Project Goals & Development projects & $\begin{array}{l}\text { Levene \& } \\
\text { Braganza (1996) }\end{array}$ \\
\hline \multirow{2}{*}{$\begin{array}{l}\text { Extent of } \\
\text { implementation }\end{array}$} & Conception projects & Gareis (1998) \\
\hline & $\begin{array}{l}\text { Position of project in the life-cycle of the product produced by the facility, or in the } \\
\text { strategic development of the parent organisation }\end{array}$ & Turner (1993) \\
\hline \multirow[b]{2}{*}{$\begin{array}{l}\text { Type of project } \\
\text { owner }\end{array}$} & $\begin{array}{cc}\text { Same client projects } & \text { Different client projects }\end{array}$ & Gareis (1991) \\
\hline & $\begin{array}{l}\text { External projects with deliverables for a } \\
\text { customer, but don't change the } \\
\text { organisation itself }\end{array}$ & $\begin{array}{l}\text { Reiss (1996); } \\
\text { Gareis (1998) }\end{array}$ \\
\hline $\begin{array}{l}\text { Projects } \\
\text { dimensions }\end{array}$ & Physical size & $\begin{array}{l}\text { Turner (1993) } \\
\text { Payne (1995) }\end{array}$ \\
\hline Complexity & Complex & Gareis (1998) \\
\hline Urgency/Priority & Differences in degree of Urgency & Payne (1995) \\
\hline Risk profile & $\begin{array}{ll}\text { High risk or uncertainty } & \text { Low risk or uncertainty } \\
\end{array}$ & Gareis (1998) \\
\hline Definition & Closed, well and rigidly defined projects & Reiss (1996) \\
\hline
\end{tabular}

Table 4: Comparative table of Multi-project related typologies and classifications.

\begin{tabular}{|c|c|c|c|}
\hline Differentiation & \multicolumn{2}{|c|}{ Multi-project related Categories } & References \\
\hline \multirow[t]{2}{*}{ Relationships } & Complete in themselves, independent & $\begin{array}{c}\text { Linked, or related projects, dependent. } \\
\text { Possibly elements of a single large } \\
\text { project. }\end{array}$ & $\begin{array}{l}\text { Morris \& Hough } \\
\text { (1987); Ireland } \\
\text { (1997); Meredith } \\
\text { \& Mantel (1995) }\end{array}$ \\
\hline & \multicolumn{2}{|c|}{ Extent of resource sharing } & $\begin{array}{l}\text { Gareis (1991) } \\
\text { [and many others } \\
\text { by implication] }\end{array}$ \\
\hline \multirow{2}{*}{ Repetitiveness } & Strangers & Runners & Reiss (1996) \\
\hline & Unique & Repetitive & Gareis (1998) \\
\hline
\end{tabular}


Table 5: Summary of construction MPE types

\begin{tabular}{|c|c|c|c|}
\hline Feature & Bounded Programmes & Target Programmes & Rolling Programmes \\
\hline Time Horizon & Limited & Variable goal & Continuous \\
\hline Programme Definition & $\begin{array}{l}\text { Closed, well and rigidly } \\
\text { defined programmes (and } \\
\text { projects) }\end{array}$ & $\begin{array}{l}\text { Variable definition, usually } \\
\text { moderate }\end{array}$ & $\begin{array}{l}\text { Open, vague and ill-defined } \\
\text { programmes (not necessarily } \\
\text { projects) }\end{array}$ \\
\hline Programme Objectives & Specific outcome based & $\begin{array}{l}\text { Moderately to well-defined } \\
\text { corporate objectives }\end{array}$ & $\begin{array}{l}\text { Gradual/incremental } \\
\text { development of network }\end{array}$ \\
\hline Project Sites & $\begin{array}{l}\text { Existing or secure network } \\
\text { properties }\end{array}$ & $\begin{array}{l}\text { Properties or land to be } \\
\text { acquired }\end{array}$ & $\begin{array}{l}\text { Properties or land to be } \\
\text { acquired }\end{array}$ \\
\hline Source of funding & Dedicated funds & $\begin{array}{l}\text { Yearly variable budget, based } \\
\text { on outlook }\end{array}$ & $\begin{array}{l}\text { Annual budget cycle funding - } \\
\text { bid \& approval on annual } \\
\text { basis }\end{array}$ \\
\hline Project Similarity & High degree of similarity & Moderate to high & Variable \\
\hline $\begin{array}{l}\text { Project Interaction } \\
\text { (Project knock-ons) }\end{array}$ & High & Moderate & Low \\
\hline $\begin{array}{l}\text { Economic Environment } \\
\text { Influence }\end{array}$ & Low & Moderate to high & High \\
\hline $\begin{array}{l}\text { Supply-chain } \\
\text { Partnering }\end{array}$ & $\begin{array}{l}\text { High potential, but limited to } \\
\text { single programmes }\end{array}$ & $\begin{array}{l}\text { Variable - but can establish } \\
\text { long-term alliance on targeted } \\
\text { work }\end{array}$ & High long-term \\
\hline Bulk Procurement & High potential & High - moderate & Variable \\
\hline $\begin{array}{l}\text { Learning \& Knowledge } \\
\text { retention }\end{array}$ & Low & Variable & High \\
\hline Creativity \& Innovation & Variable & Moderate & $\begin{array}{l}\text { High (although habituation } \\
\text { may reverse) }\end{array}$ \\
\hline $\begin{array}{l}\text { Workload certainty \& } \\
\text { continuity }\end{array}$ & $\begin{array}{l}\text { High short-term certainty \& } \\
\text { continuity, } \\
\text { Low long-term }\end{array}$ & $\begin{array}{l}\text { Variable (mitigated } \\
\text { stochasticity) } \\
\text { Medium term }\end{array}$ & $\begin{array}{l}\text { Low short-term certainty \& } \\
\text { continuity } \\
\text { Better long-term }\end{array}$ \\
\hline $\begin{array}{l}\text { Subject to schedule and } \\
\text { other changes } \\
\text { (flexibility) }\end{array}$ & $\begin{array}{l}\text { Low over life, may be high in } \\
\text { the very short-term }\end{array}$ & $\begin{array}{l}\text { Constant change made to } \\
\text { targets }\end{array}$ & High long-term flexibility \\
\hline
\end{tabular}


Table 6: Features of Bounded Programme Types

\begin{tabular}{|c|c|c|}
\hline Feature & Bounded Programmes & Detailed Description \\
\hline Time Horizon & Limited & $\begin{array}{l}\text { The highly defined nature of these types is typified by a fixed } \\
\text { time horizon for the programme, with no prospect of } \\
\text { continuance. }\end{array}$ \\
\hline Programme Definition & $\begin{array}{l}\text { Closed, well and rigidly } \\
\text { defined programmes (and } \\
\text { projects) }\end{array}$ & $\begin{array}{l}\text { Programmes are well defined with a clear understanding of the } \\
\text { programme's aims and therefore the construction programme can } \\
\text { be specified earlier. }\end{array}$ \\
\hline Programme Objectives & Specific outcome based & $\begin{array}{l}\text { An extension of the former features with objectives focussed on } \\
\text { a specific outcome that has been well-defined. }\end{array}$ \\
\hline Project Sites & $\begin{array}{l}\text { Existing or secure network } \\
\text { properties }\end{array}$ & $\begin{array}{l}\text { In order for the programme to be so highly defined, a stable } \\
\text { network of sites is required, and is therefore usually owned or } \\
\text { contractually secure. }\end{array}$ \\
\hline Source of funding & Dedicated funds & $\begin{array}{l}\text { Due to the specificity of the programme, funding will have been } \\
\text { allocated for the completion of the programme, although not all } \\
\text { necessarily transferred at commencement. }\end{array}$ \\
\hline Project Similarity & High degree of similarity & $\begin{array}{l}\text { The programme that is so well defined assumes a high degree of } \\
\text { understanding of the nature of work involved, and therefore } \\
\text { further assumes that for such an understanding to exist the sites } \\
\text { and projects must show high degrees of similarity. }\end{array}$ \\
\hline \multirow[t]{2}{*}{ Project Interaction } & \multirow[t]{2}{*}{ High } & $\begin{array}{l}\text { Following-on from the former, project interdependency is } \\
\text { predicted as being high due to the high probability of a } \\
\text { production/roll-out-based approach. Such a firmly defined } \\
\text { programme would tend to attract a more rigid planning approach, } \\
\text { and hence interdependency. }\end{array}$ \\
\hline & & $\begin{array}{l}\text { Further, the programme is dependent on completion of all } \\
\text { projects, thereby linking all project outcomes. }\end{array}$ \\
\hline $\begin{array}{l}\text { Economic Environment } \\
\text { Influence }\end{array}$ & Low & $\begin{array}{l}\text { The closed and decided nature of these programmes reduces the } \\
\text { influence that economic fluctuations have on the rate and } \\
\text { completion of projects, and the programme overall. }\end{array}$ \\
\hline Supply-chain Partnering & $\begin{array}{l}\text { High potential, but limited to } \\
\text { single programmes }\end{array}$ & $\begin{array}{l}\text { The certainty associated with these programmes would suite } \\
\text { partnered arrangements, however the limited time-frame may } \\
\text { mean it is limited to a single programme. }\end{array}$ \\
\hline Bulk Procurement & High potential & $\begin{array}{l}\text { The similarity of projects, high certainty, bulk volumes and } \\
\text { strong definitions make these ideal candidates for bulk } \\
\text { procurement initiatives. }\end{array}$ \\
\hline $\begin{array}{l}\text { Learning \& Knowledge } \\
\text { retention }\end{array}$ & Low & $\begin{array}{l}\text { As procurement would tend to be outsourced, and the } \\
\text { programme within a fixed period, most knowledge gained would } \\
\text { be lost as staff moves away from the client organisation, and } \\
\text { systems are dismantled. }\end{array}$ \\
\hline \multirow{3}{*}{ Creativity \& Innovation } & \multirow{3}{*}{ Low } & $\begin{array}{l}\text { The nature of bounded programmes dictates that a fairly high } \\
\text { degree of design and planning fixity has been decided, }\end{array}$ \\
\hline & & $\begin{array}{l}\text { Again linked to the former point, the opportunity for identifying } \\
\text { areas of improvement and implementing such changes within the } \\
\text { life of the programme is low, }\end{array}$ \\
\hline & & $\begin{array}{l}\text { Opportunity exists if early decisions are made to implement an } \\
\text { innovative product or approach. }\end{array}$ \\
\hline $\begin{array}{l}\text { Workload certainty \& } \\
\text { continuity }\end{array}$ & $\begin{array}{l}\text { High short-term certainty \& } \\
\text { continuity, } \\
\text { Low long-term }\end{array}$ & $\begin{array}{l}\text { Workloads and general continuity are certain in the short-term, } \\
\text { as the programme is planned and executed in detail, however } \\
\text { continuity or serial contracts would be highly uncertain. }\end{array}$ \\
\hline $\begin{array}{l}\text { Subject to schedule and } \\
\text { other changes } \\
\text { (flexibility) }\end{array}$ & $\begin{array}{l}\text { Low over life, may be high } \\
\text { in the very short-term }\end{array}$ & $\begin{array}{l}\text { Within programme changes and flexibility should be minimal } \\
\text { within a rigid and mitigable internal environment. }\end{array}$ \\
\hline
\end{tabular}


Table 7: Features of Rolling programme types

\begin{tabular}{|c|c|c|}
\hline Feature & Rolling Programmes & Detailed Description \\
\hline Time Horizon & Continuous & $\begin{array}{l}\text { These programmes are unbounded, continuing without any fixed } \\
\text { timeframe. }\end{array}$ \\
\hline Programme Definition & $\begin{array}{l}\text { Open, vague and ill-defined } \\
\text { programmes (not necessarily } \\
\text { projects) }\end{array}$ & $\begin{array}{l}\text { Programmes are generally undefined with a continual yet } \\
\text { stochastic arrival of projects in the programme. Projects within } \\
\text { the programme may however be well-defined. Programme } \\
\text { certainty is low and subject to constant change. }\end{array}$ \\
\hline Programme Objectives & $\begin{array}{l}\text { Gradual/incremental } \\
\text { development of network }\end{array}$ & $\begin{array}{l}\text { The objectives relating to these programmes are gradual rather } \\
\text { step-change programmes, focussed on continuous network } \\
\text { expansion or development, as needs dictate. }\end{array}$ \\
\hline Project Sites & $\begin{array}{l}\text { Properties or land to be } \\
\text { acquired }\end{array}$ & $\begin{array}{l}\text { Properties may require purchase or acquisition from } 3^{\text {rd }} \text { parties } \\
\text { which significantly increases uncertainty. }\end{array}$ \\
\hline Source of funding & $\begin{array}{l}\text { Annual budget cycle funding - } \\
\text { bid \& approval on annual } \\
\text { basis }\end{array}$ & $\begin{array}{l}\text { Due to the nature of the programme, funding will be annual, } \\
\text { depending on the proposed works for the year. Funding will } \\
\text { usually have to be applied for and justified through budget } \\
\text { cycles. }\end{array}$ \\
\hline Project Similarity & Variable & $\begin{array}{l}\text { Projects being individually initiated, may be dissimilar. Although } \\
\text { an organisation with strong brands may have very similar } \\
\text { facilities. }\end{array}$ \\
\hline \multirow[t]{2}{*}{ Project Interaction } & \multirow[t]{2}{*}{ Low } & $\begin{array}{l}\text { As mentioned previously, projects within the programme are } \\
\text { independently initiated, and are usually independently procured. } \\
\text { Management resources may overlap with other projects though. }\end{array}$ \\
\hline & & $\begin{array}{l}\text { Similarly each project independently contributes to the } \\
\text { organisation, not usually requiring the others to be completed. }\end{array}$ \\
\hline $\begin{array}{l}\text { Economic Environment } \\
\text { Influence }\end{array}$ & High & $\begin{array}{l}\text { The open nature of these programmes relies heavily upon } \\
\text { economic indicators to determine the rate and number of projects } \\
\text { to be initiated within a given assessment period. }\end{array}$ \\
\hline $\begin{array}{l}\text { Supply-chain } \\
\text { Partnering }\end{array}$ & High & $\begin{array}{l}\text { Repeat work with selected suppliers very likely as long-term } \\
\text { work relationships establish, however high short-term } \\
\text { uncertainties means low client commitment to work, therefore } \\
\text { potential limited. }\end{array}$ \\
\hline Bulk Procurement & Variable & $\begin{array}{l}\text { High potential for components is possible depending on } \\
\text { standardisation and client's buying power to order ahead of } \\
\text { projects actually being initiated. }\end{array}$ \\
\hline $\begin{array}{l}\text { Learning \& Knowledge } \\
\text { retention }\end{array}$ & High & $\begin{array}{l}\text { As programmes are on-going there is usually a high level of in- } \\
\text { house management within the client, so that knowledge retention } \\
\text { is high, however supplier knowledge may be lost if workloads } \\
\text { are not sustained and personnel are lost. }\end{array}$ \\
\hline Creativity \& Innovation & $\begin{array}{l}\text { High (although habituation } \\
\text { may reverse) }\end{array}$ & $\begin{array}{l}\text { Again the on-going repetitive nature of the programme allows } \\
\text { innovative solutions to be tested and implemented if found to be } \\
\text { beneficial. These programmes have the advantage of 'perpetuity' } \\
\text { to allow testing of ideas and solutions, potential savings are } \\
\text { massive. }\end{array}$ \\
\hline $\begin{array}{l}\text { Workload certainty \& } \\
\text { continuity }\end{array}$ & $\begin{array}{l}\text { Low short-term certainty \& } \\
\text { continuity } \\
\text { Better long-term }\end{array}$ & $\begin{array}{l}\text { Continuity of projects and the overall process are certain in the } \\
\text { long-term, however highly variable over the short and medium- } \\
\text { term, making them very unstable. Workloads are therefore } \\
\text { uncertain and fluctuate between years. }\end{array}$ \\
\hline $\begin{array}{l}\text { Subject to schedule and } \\
\text { other changes } \\
\text { (flexibility) }\end{array}$ & High long-term flexibility & $\begin{array}{l}\text { The very nature of these programmes makes them highly } \\
\text { vulnerable to changes as clients maintain flexibility and react to } \\
\text { changes in the environment. }\end{array}$ \\
\hline
\end{tabular}


Table 8: Features of Target programme types

\begin{tabular}{|c|c|c|}
\hline Feature & Target Programmes & Detailed Description \\
\hline Time Horizon & Variable goal & $\begin{array}{l}\text { The timeframe of these programmes is usually defined as a } \\
\text { Target (usually between } 3 \text { and } 5 \text { years), although this is subject } \\
\text { to change as circumstances change. }\end{array}$ \\
\hline Programme Definition & $\begin{array}{l}\text { Variable definition, usually } \\
\text { moderate }\end{array}$ & $\begin{array}{l}\text { The programme is better defined than the rolling programme, but } \\
\text { not as rigid as Bounded programmes. Projects may be well- } \\
\text { defined, and targets may likewise be very well defined although } \\
\text { not easily attainable. }\end{array}$ \\
\hline Programme Objectives & $\begin{array}{l}\text { Moderately to well-defined } \\
\text { corporate objectives }\end{array}$ & $\begin{array}{l}\text { Corporate objectives, giving rise to these programmes, are } \\
\text { usually well-defined with certain objectives, however with the } \\
\text { proviso that they are subject to environmental forces. }\end{array}$ \\
\hline Project Sites & $\begin{array}{l}\text { Properties or land to be } \\
\text { acquired }\end{array}$ & $\begin{array}{l}\text { Properties may require purchase or acquisition from } 3^{\text {rd }} \text { parties } \\
\text { which significantly increases uncertainty. }\end{array}$ \\
\hline Source of funding & $\begin{array}{l}\text { Yearly variable budget, based } \\
\text { on outlook }\end{array}$ & $\begin{array}{l}\text { Funding may be allocated annually through the budget according } \\
\text { to the target figures. Annual application may not be formally } \\
\text { required although depends on organisational structures. }\end{array}$ \\
\hline Project Similarity & Moderate to high & $\begin{array}{l}\text { Projects within these programmes are usually somewhat related } \\
\text { and therefore similar in nature, if not identical in design and } \\
\text { specification. The Target number implies quite high project } \\
\text { similarity. }\end{array}$ \\
\hline Project Interaction & Moderate & $\begin{array}{l}\text { Related to the previous feature, the project interaction is } \\
\text { moderate, although it can be significant in resource allocation. } \\
\text { Project management and suppliers resources can be stretched if } \\
\text { these projects overlap. Completion of all target projects on the } \\
\text { programme is usually important. }\end{array}$ \\
\hline $\begin{array}{l}\text { Economic Environment } \\
\text { Influence }\end{array}$ & Moderate to high & $\begin{array}{l}\text { The target figures are subject to economic influences, which may } \\
\text { slow or speed the rate of projects comprising the programme } \\
\text { target, or else may require the target numbers to change in } \\
\text { conformance with the economic outlook. }\end{array}$ \\
\hline $\begin{array}{l}\text { Supply-chain } \\
\text { Partnering }\end{array}$ & $\begin{array}{l}\text { Variable - but can establish } \\
\text { long-term alliance on targeted } \\
\text { work }\end{array}$ & $\begin{array}{l}\text { Similar to Rolling. Suppliers have good ideas of workloads, yet } \\
\text { clients may not commit contractually due to the flexibility they } \\
\text { wish to retain. Long-term relationships and repeat work possible. }\end{array}$ \\
\hline Bulk Procurement & High - moderate & $\begin{array}{l}\text { Like above, the potential is high should the target numbers be } \\
\text { stable, however with variability benefits of bulk procurement } \\
\text { decrease. }\end{array}$ \\
\hline $\begin{array}{l}\text { Learning \& Knowledge } \\
\text { retention }\end{array}$ & Variable & $\begin{array}{l}\text { Learning and knowledge retention depends on the extent of } \\
\text { supplier repeat-work and whether the client outsources or retains } \\
\text { management internally. Outsourcing is common for maintaining } \\
\text { flexibility, but may result in loss of knowledge by the client. }\end{array}$ \\
\hline Creativity \& Innovation & Moderate & Potentially high, depending on programme definition. \\
\hline $\begin{array}{l}\text { Workload certainty \& } \\
\text { continuity }\end{array}$ & $\begin{array}{l}\text { Variable (mitigated } \\
\text { stochasticity), medium term }\end{array}$ & $\begin{array}{l}\text { Workloads are usually more stable than Rolling programmes, } \\
\text { although not as rigid as Bounded. The Target figures provide the } \\
\text { focus for increasing certainty and continuity, however high } \\
\text { environmental influences affect the programme. }\end{array}$ \\
\hline $\begin{array}{l}\text { Subject to schedule and } \\
\text { other changes } \\
\text { (flexibility) }\end{array}$ & $\begin{array}{l}\text { Constant change made to } \\
\text { targets }\end{array}$ & $\begin{array}{l}\text { Target figures are adjusted according to changes in the } \\
\text { environment, although may be rigidly held if the corporate } \\
\text { objectives giving rise to the programmes are maintained. }\end{array}$ \\
\hline
\end{tabular}


Table 9: Validation of typology programme models through case replication (Key: $\checkmark$ characteristic agrees with programme type, $\boldsymbol{x}$ characteristic does not agree with programme type (closest type), ? unknown for the case).

\begin{tabular}{|c|c|c|c|c|c|c|c|c|c|}
\hline $\begin{array}{l}\text { Features } \\
(* \text { defining features) }\end{array}$ & 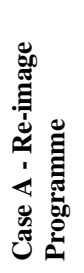 & 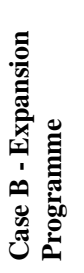 & 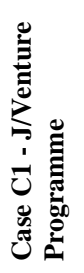 & 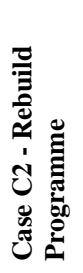 & 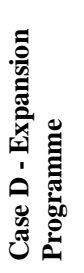 & 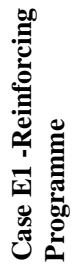 & 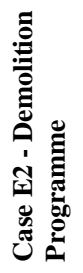 & 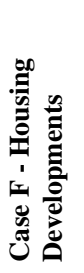 & 岕 \\
\hline Time Horizon* & \multirow{4}{*}{ 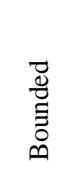 } & \multirow{4}{*}{ 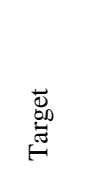 } & \multirow{4}{*}{ 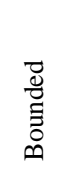 } & \multirow{4}{*}{ 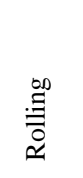 } & \multirow{4}{*}{ 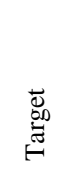 } & \multirow{4}{*}{ 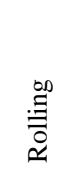 } & \multirow{4}{*}{ 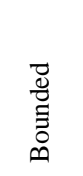 } & \multirow{4}{*}{ 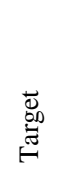 } & \multirow[b]{4}{*}{ ' } \\
\hline Programme Definition* & & & & & & & & & \\
\hline Programme Objectives* & & & & & & & & & \\
\hline Project Sites* & & & & & & & & & \\
\hline Source of funding & $\checkmark$ & $\checkmark$ & $\checkmark$ & $\checkmark$ & $x$ & $\checkmark$ & $?$ & $\checkmark$ & $6 / 7$ \\
\hline Project Similarity & $\checkmark$ & $\checkmark$ & $\checkmark$ & $\checkmark$ & $\checkmark$ & $\checkmark$ & $\checkmark$ & $x$ & $7 / 8$ \\
\hline Project Interaction & $\checkmark$ & $\checkmark$ & $?$ & $\checkmark$ & $\checkmark$ & $x$ & $?$ & $\checkmark$ & $5 / 6$ \\
\hline Economic Environment Influence & $\checkmark$ & $\checkmark$ & $?$ & $\checkmark$ & $\checkmark$ & $\checkmark$ & $\checkmark$ & $\checkmark$ & $7 / 7$ \\
\hline Supply-chain Partnering & $\checkmark$ & $\checkmark$ & $\checkmark$ & $\checkmark$ & $\checkmark$ & $\checkmark$ & $\checkmark$ & - & $7 / 7$ \\
\hline Bulk Procurement & $\checkmark$ & $x$ & $\checkmark$ & $\checkmark$ & $\checkmark$ & $\checkmark$ & $\checkmark$ & - & $6 / 7$ \\
\hline Learning \& Knowledge retention & $\checkmark$ & $\checkmark$ & $\checkmark$ & $\checkmark$ & $\checkmark$ & $\checkmark$ & $?$ & $\checkmark$ & $7 / 7$ \\
\hline Creativity \& Innovation & $\checkmark$ & $\checkmark$ & $\checkmark$ & $\checkmark$ & $\checkmark$ & $\checkmark$ & $?$ & $\checkmark$ & $7 / 7$ \\
\hline Workload certainty \& continuity & $\checkmark$ & $\checkmark$ & $\checkmark$ & $\checkmark$ & $\checkmark$ & $\checkmark$ & $\checkmark$ & $\checkmark$ & $8 / 8$ \\
\hline Schedule \& other changes (flexibility) & $\checkmark$ & $\checkmark$ & $\checkmark$ & $\checkmark$ & $\checkmark$ & $\checkmark$ & $\checkmark$ & $\checkmark$ & $7 / 7$ \\
\hline TOTAL (Ave 93\%) & $10 / 10$ & $9 / 10$ & $8 / 8$ & $10 / 10$ & $9 / 10$ & $9 / 10$ & $6 / 6$ & $7 / 8$ & \\
\hline
\end{tabular}

